\title{
Marketing Strategy and Organizational Performance of Selected Food and Beverage Companies in the Pandemic Era
}

\author{
ODUWOLE, Wahid Kolawole \\ Department of Marketing, School of Business and Management Studies \\ Yaba College of Technology Yaba Lagos \\ OLAWORE, Olusegun Paul \\ School of Management and Business Adminisration, Department of Marketing, \\ Lagos State Polytechnic, Ikorodu \\ JAMES, Mutiat Temitope \\ School of Management and Business Adminisration \\ Department Business Administraion, Lagos State Polytechnic \\ BABAJIDE, David Adesina \\ Department of Banking and Finance, School of Business and Management Studies \\ Yaba College of Technology Yaba Lagos
}

\begin{abstract}
The need for strategic marketing arose in quest for organisations building consumer base through Consumer's satisfaction. It is compulsory for every organizations to achieve this through effective marketing at all-time hence. A successful marketing strategy must tell an organization where they would want to be on a long-term basis. This process is constrained by the business environment. During this era of pandemic (Covid-19) businesses were constrained further by measures adopted by various government in limiting the rate on spread of the deadly virus and its variants. Hence organizations devise various strategy to achieve its marketing objectives. The main objective of this study is to determine the effect of strategic marketing adopted in the pandemic era on organizational performance specifically the paper determine the relationship between strategic marketing adopted in the pandemic era (Covid-19) and organization profitability, productivity and customers' satisfaction.

Data were sourced from primary sources of data using questionnaire as instrument of data collection, it was administered among selected respondents from Seven Up Bottling Company. Data collected were analyzed using Non Parametric Statistical tool of Chi Square. It was discovered that internet marketing and other creative marketing strategies adopted during Covid-19 Era has significant relationship to organization profitability and her productivity during Covid-19 lockdown. Based on these findings, it was recommended that target market share must change from the innovators to the more typical segments that constitute the mass market and marketing mix should also change during the growth stage.
\end{abstract}

Keywords: Business Environment; Competitive Advantage; Market Orientation

DOI: $10.7176 /$ RJFA/12-20-07

Publication date:October $31^{\text {st }} 2021$

\section{Section I: Introduction}

\subsection{Background to the Study}

Organizations exist for a variety of purposes most importantly to satisfy human wants by producing goods and services for commercial purposes. In pursuit of these goals organizations relies on various levels of plans and strategies formulated routinely to fit the changing business environment constraint by the available resources to the organization. Strategy is the organized deployment of resources to achieve specific objectives, something that business and warfare have in common. Therefore in any organization, customers' satisfaction is in the eye of the storm, customer patronage provides the basis for a stable and growing market share.

Anetoh and Moguluwa, (2018) opined that customer patronage entails the level of consent or support expressed in order to stir customer's exhibition of repurchase or repeat intention and satisfaction towards using a brand or product. The extent of patronage is stimulated by customer's behaviourial, attitudinal and psychological commitment and willingness to incur extra cost towards repurchasing a brand or product amidst other alternatives (Perutkova \& Parsa, 2010). Kotler and Andreasen, (2006) defined marketing as the process of planning and executing programmed designed, make, and maintain beneficial exchange relationships with target audiences for the purposes of satisfying individual and organizational objectives.

Marketing strategy is seen as the marketing logic by which the business will hope to achieve its marketing objectives. Businesses operate in environments susceptible to activities, crisis and events that significantly ignite intense changes that could enhance, retard, stifle or shrink their sales, patronage, and profitability including 
transforming their business operational strategies. As such an emergency or crisis situation (as the COVID-19 Pandemic) can affect organizations (i.e. small, medium and big) through the disruption of operations, plans, supply chain, and modus operandi based on the ensuing protocols (as restrictions, closures, quarantines and so on), measures and reactions for tackling a pandemic. Motti (2020) sees COVID-19 as a coronary disease and fast spreading global invasive pandemic that influences individuals, organizations, and Governments welfare, routine and functions respectively, thereby, compelling them to responsively re-strategizing and altering their pattern for maneuvering and navigating an environment (like business) based on the emerging experiences and challenges on what is termed as the "new normal" in the society.

Consumer's satisfaction even in this era of pandemic, it is so important that many organizations allocate large portion of their resources to pursue this objective. One of the ways to achieve consumer's satisfaction is through effective marketing strategies which are developed around the identification of consumers' expectations using such dimensions as product, price, place, promotion along with organization's distinctive competence (Shaw, 2012). Virtually everything the marketers do is done with the ultimate aim of getting or attracting the potential consumers who shall be loyal to them for a lifetime.

\subsection{Statement of Problem}

Marketing strategy adopted from time to time focuses on integrating marketing that respond to the prevailing business environment which must be tailored to achieve organization's goals and corporate objectives. In manufacturing sector, the consumer is made to bear the brunt of increase in cost of production for highly elastic goods. Nevertheless, consumers also have become cautions in his spending, although, hardly can they do without buying but they now buys the most essential products for survival. However the prevailing circumstances has altered responses of both the consumers and the manufacturers. Response to Covid-19 pandemic has compelled most countries to shutdown business activities with government of most developed economy supplying most of the need of the citizens. These conditions has force the marketers to think out of the boxes and device new approaches in marketing their goods and services.

Non-utilization of appropriate marketing strategies by business organization and institutions has not be adequately addressed, but with the prevailing circumstances, marketing strategy adopted by the organization and its effectiveness formed the problem of this research. Competitiveness and the nature of business environment in Nigeria has been attributed to the high competitions and rivalry among manufacturing sector in Nigeria.

Although the prevailing conditions throughout the world are gloomy due to the attack of COVID-19 even to different waves of the pandemic. The third waves of named Covid-19 w Delta variant has an increasing populace affected by the coronavirus, nations worldwide have started another round of lockdowns. Most of the manufacturers of Fast Moving Consumers Goods (FMCG) along with some other sectors are facing massive trouble attending to customer queries physically, solving their issues, and so on. Every sector is turning to virtual mode, all the work done by the managers with clients has to be conducted virtually as physical contact being stopped by the governments.

This paper therefore explore the prevailing internet marketing practices adopted by manufacturing sector in enhance customer satisfaction and influence purchase intention.

Measuring the effectiveness of each of these strategies in attracting eyeballs and final purchase holds enormous implications for all sectors' existing and future marketing practices. Due to this pandemic, to establish the relationship between internet marketing practices adopted by manufacturers and customers' satisfaction and influence purchase intention affected the clients.

\subsection{Research Questions}

Based on the objectives enumerated above, this research work attempted to address the following research questions:

i). What is the relationship between internet marketing and other creative marketing strategies adopted during Covid-19 Era and organization profitability?

ii). What is the effect of internet marketing and other creative marketing strategies adopted during Covid-19 Era on organization productivity?

iii). What is the impact of internet marketing and other creative marketing strategies adopted during Covid-19 Era on customers' satisfaction.

\subsection{Objective of Study}

The main objective of this study is to determine the effect of internet based marketing strategies on customer loyalty during global pandemic (Covid-19). Specifically, this study seeks to achieve the following specific objectives to:

i). Determine the relationship between the pandemic (Covid-19) and strategic and other creative marketing strategies adopted. 
ii). Determine the effect of strategic and other creative marketing strategies adopted during Covid-19 Era on organization profitability.

iii). Determine the effect of creative marketing strategies adopted during Covid-19 Era on organization productivity.

\subsection{Research Hypotheses}

Hypothesis I

Ho: There is no significant relationship between the pandemic (Covid-19) and strategic and other creative marketing strategies adopted.

\section{Hypothesis II}

Ho: Strategic and other creative marketing strategies adopted during Covid-19 Era does not have significant effect on organization profitability.

Hypothesis III

Ho: Strategic and other creative marketing strategies adopted during Covid-19 Era does not have significant effect on organization productivity.

\subsection{Significance of the Study}

The market focused strategies is defined as the firms reactive and proactive abilities to satisfy customers' needs and aspirations by the consistent and continuous configuring and reconfiguring of its capabilities and resources. Marketing activities play a vital role in the survival and growth of organizations. Marketing strives to service and satisfy human insatiable needs and wants. The marketing strategies acted as guide for competitive advantage to business by examining through its application to marketing is a veritable vehicle for achieving socio-economic transformation of a country.

This research is an important aspect public life even in this era of uncertainty, this research will serves as a reference materials for other researchers and students in field of management sciences. Apart from this, managers and researchers would benefit from a deeper understanding of how marketing strategy and other creative marketing strategies adopted during Covid-19 Era has impacted on organization performance and how it relates and works with other important marketing concepts, by revealing the way it collaborates with them to effect outcome.

Similarly, this research work will reveal how managers and marketing representatives can use marketing strategies such as market attractiveness competitive position, aggressiveness and defensiveness to achieve corporate objectives of profitability, productivity, effectiveness and so on.

\subsection{Scope and Delimitations of the Study}

The research work is concerned only with examining the impact of corporate repositioning through effective internet marketing and other creative marketing strategies adopted during Covid-19 Era with reference to some selected manufacturer of FMCG in Lagos State. Generally, the scope of the study is limited to some of the marketing strategies adopted by these selected firms ie 7 UP bottling company, Nigerian Bottling Company ana 3 othres company during Covid-19 era in achieving its corporate goal and objectives. Also, the study seeks to identifies which of these strategies is frequently utilized by the company to achieve is corporate objectives.

Essentially, the scope of this study is limited to five marketing strategies of aggressiveness, defensiveness, adaptability, specialization and cooperation which shall be intensively considered in the study.

\subsection{Organization of the Study}

This paper is divided into four sections, section one is the general introduction of the study, contains the background of the study, the objectives of the study, problems of the study, research questions, research hypotheses to be tested, the scope of the study and significance of the study. Section two deals with literature review; this reviews the work of various authors and scholars on the subject matter. While section three is on the research methodology of the study and testing of hypotheses formulated as well as the discussion of the results. While and section four is the summary of findings, conclusion and recommendations.

\section{Section Two: Literature Review \\ 2.1 Introduction}

Marketing effectiveness research has remained an important field of study all over the world. This is probably because marketing is one of the major areas where rapid obsolescence of objectives, policies, strategies, and programmes are a constant possibility. It poses formidable challenges to researchers, often times, the tendency is to base the evaluation of a company's marketing effectiveness on its performance on sales growth, market share, and profitability. The assumption has always been that the high-performing company tends to have good marketing leadership while the poor-performing company tends to have deficient marketing leadership. 
Marketing effectiveness of a company or a division is reflected in the degree to which it exhibits five major attributes of a marketing orientation: customer orientation, integrated marketing organization, adequate marketing information, strategic orientation and operational efficiency. In recent years, the idea of strategy has received increasing recognition in management literature. Series of publications have appeared dealing with product line strategy, marketing strategy; diversification strategy, and business strategy. They also suggested appropriate changes in the product/service strategy based on the economic climate and business cycle (Culiwick, 2005 \& Hannal et al, 2006).

This interest grew out of a realization that an organization needs a well-defined scope and growth direction, that objectives alone do not meet this bid but requires additional decision rules in order to enable an organization to have orderly and profitable growth. This kind of arrangement and guidelines has been defined as strategy. Actually, Santoki1 and Parekh (2020) opined that marketing effectiveness is not so simple, because of the rapid changes in the marketing environment, it is a normal practice for each company to engage in periodic reassessment of its overall approach to the market place. This challenges were made worse by Corona Virus attack on global level which has thrown many challenges to all the sectors of the economy business inclusive. It has shaken the economies of developed, underdeveloped and developing countries. In such challenging times some businesses have edge over other businesses relying more on internet marketing.

\subsection{Conceptual Review}

\subsubsection{Concept of Marketing and Marketing Strategy}

Marketing has been defined as the management function responsible for identifying, anticipating and satisfying customer requirements profitably (Osuagwu and Acumba; 1998). Marketing is, therefore, both a philosophy and a set of techniques which address such matters as research, product design and development, pricing, packaging, sales and sales promotion, advertising, public relations, distribution and after-sales service. These activities define the broad scope of marketing and their balanced integration within a marketing plan is known as the marketing mix. Doyle (2000) suggests that marketing is the management process that seeks to maximize returns to shareholders by creating a competitive advantage in providing, communicating and delivering value to thereby developing a long-term relationship with them. The specific contribution of marketing in the organization lies in the formulation of strategies to choose the right customer, build relationships of trust with them and create a competitive advantage (Doyle, 2000). Marketing strategy consists of an internally integrated but externally focused set of choices about how the organization addresses its customers in the context of a competitive environment. He opined that strategy has five elements: it deals with where the organization plans to be active how it will get there; how it will succeed in the marketplace; what the speed and sequence of moves will be; and how the organization will obtain 1ts (Hambrick and Fredrickson 2001).

However, Kotler and Keller (2006) pointed that marketing is a philosophy that encourages the organization to ensure that the needs and wants of customers in selected target markets are reflected in all its actions and activities while recognizing constraints imposed by society. This marketing concept first received formal recognition in 1952 by one of its leading exponents, the General Electric organization - the marketing concept (General Electric Organization, 1952).

Three aspects of this statement are pointed as: the customer orientation; the profit orientation; and the emphasis on integrated organization effort. These three aspects are fundamental to the adoption of the marketing concept. Marketing means, therefore, being oriented to the needs of customers rather than emphasizing what is convenient to produce. Effective marketing requires that the organization analyses the needs that its products are supposed to satisfy.

Anderson (2020) suggested that the real lesson of a marketing philosophy is at better performing organizations recognize the basic and enduring nature of the customer needs they are attempting to satisfy. It is the technology of want satisfaction which is transitory. The products and services used to satisfy customer needs and wants change constantly. The adoption of a marketing philosophy confers specific authority and responsibility within the organization in regard to the provision, communication and delivery of customer value. Marketing is concerned with all parts of the organization; it is more than a set of tools, it is an orientation which pervades the thinking of the organization as a whole.

Marketing strategy consists of an internally integrated but externally focused set of choices about how the organization addresses its customers in the context of a competitive environment. He opined that strategy has five elements: it deals with where the organization plans to be active; how it will get there; how it will succeed in the marketplace; what the speed and sequence of moves will be; and how the organization will obtain profits (Hambrick and Fredrickson 2001). However, Kotler and Keller (2006) pointed that marketing is a philosophy that encourages the organization to ensure that the needs and wants of customers selected target markets are reflected in all its actions and activities while recognizing constraints imposed by society. This marketing concept first received formal recognition in 1952 by one of its leading exponents, the General Electric Organization (the marketing concept General Electric Organization, 1952). 
Aremu and Lawal (2012) sees strategy as a pattern of resource allocation decisions made throughout an organization. This encapsulates both desired goals and beliefs about what are acceptable and most critically unacceptable means for achieving them. Aremu and Lawal, (2012) posited that strategy implies the analysis of the market and its environment, customer buying behaviour, competitive activities and the need and capabilities of marketing intermediaries. Marketing strategy therefore, can be defined as a method by which a firm attempts to reach its target markets. Marketing strategy must focus on delivering greater value to customers and the firm at a lower cost Chiliya et al, (2009). Owomoyela et al, (2013) also sees marketing strategy as ways of providing a quality product that satisfies customer needs, offering affordable price and engaging in wider distribution and back it up with effective promotion strategy. Marketing strategy is a vital prerequisite of Industry's ability to strengthen its market share and minimize the impact of the competition.

There exposition can be deduced from these concepts-the customer orientation; the profit orientation; and the emphasis on integrated organization effort. These three aspects are fundamental to the adoption of the marketing concept. Marketing means being oriented to the needs of customers rather than emphasizing what is convenient to produce. Effective marketing requires that the organization analyses the needs that its products are supposed to satisfy. Anderson (2021) suggested that the real lesson of a marketing philosophy is that better performing organizations recognize the basic and enduring nature of the customer needs they are attempting to satisfy. It is the technology of want satisfaction which is transitory, the products and services used to satisfy customer needs and wants change constantly.

The adoption of a marketing philosophy confers specific authority and responsibility within the organization in regard to the provision, communication and delivery of customer value. Marketing is concerned with all parts of the organization; it is more than a set of tools, it is an orientation which pervades the thinking of the organization as a whole. Li (2011) in agreement with Hill, (1994) and Conant et al., (1990) opined that marketing proficiency of a firm is defined as an ability to understand who the customer are and how to meet their needs better than the competitors can. But Houston (2019) observed that marketing concept centers on the management of market "exchange" between customers and organizations. It helps organizations to accomplish exchange determined goals more efficiently.

Organization competing in an industry has a competitive strategy whether explicit or implicit. Strategy may have been originated explicitly or implicitly through a well related planning process or it may have developed implicitly through the activities of the various functional arms of the organization (Achumba, 2000). He further identified the extent of the success of a company to a large extent depends upon how well it formulates its policy and strategy in the light of the environment which is in a constant fluky how well it defines and articulates in as well as their implementation. Chandler (2016) framed the significance of marketing strategy in this comment Business is like war in one respect, if its grand strategy is correct, any number of practical errors can be made and yet the enterprises prove successful, in the same vein Boohmger (2003) opined that managers will be judge not by the nimbleness of their tactics but by the robustness of their strategic decisions for the organization they managed.

Marketing practice tended to be seen as a creative industry that included advertising, distribution and selling. The philosophy of marketing concept teaches that to succeed in any business, the customer must be the centerpiece of a bank's activities. The saying "the customer is king" "the customer is a dictator, the customer is god, are all bone out of the philosophy. Marketing is an integral part of the strategic planning process. It represents a fundamental philosophy of an organization in which management recognizes that the organization should be market driven, and thus adopts strategies that focus on meeting consumer needs coincident with a profit plan and should have a marketing plan.

Business success is not the result of one brilliant accidental strategy, rather the result of a well-articulated continuous response to environment and in thoughtful adaptations to it marketing strategy is a means by which marketing goals are to be achieved. (David, 1995), it explains how sales response function help a marketing manager allocate the firm's marketing efforts.

There are diverse definitions of marketing strategy and such definitions reflect numerous perspectives. However, the summary is that marketing strategy provides the avenue for making use of the resources of an organization in order to ascertain its set goals and objectives. Marketing strategy is defined as a given market area, the proper distribution of resources to support enterprises to win competitive advantage.

\subsubsection{Concept of Organizational Performance}

It can be noticed the fact that an entity is successful when it is efficient, effective and economical. Therefore, to be successful means combining all three variables, the combination of which reflects the performance level of an entity. Daniel (2018) described organizational performance using the 3E: efficiency, efficacy and economies, as forms of manifestation But MihaiRistea (2002) argued that organizational performance can proxy using these three concepts; efficiency, economies and efficacy. He designed the model to relate the concepts thus;

Performance $=$ profitability + Sales Volume + Market share.

Efficiency consists in either using a quantity given by resources, aimed at the highest level of the achieved 
results, or reducing the quantity of the used resources with the aim of achieving a predetermined result. Economies consist in providing the means, the necessary resources to performing an activity at the minimum cost. Efficacy is determined by achieving or exceeding the predetermined results to the actual results made throughout the development of the activity. This represents the ability of the enterprise to meet and even exceed the expectations of users of the accounting information (shareholders/associates, clients, suppliers, employees, government) at the same time with reaching the predetermined organizational objectives. An entity reaches efficacy when it manages to improve the way of using all sources which are available to improve on its profitability, sales volume and increase its market share

Profit: Profit is defined as a financial gain especially the difference between the amounts earned and amount spent in buying, operating, or producing something. Profit can also be seen as surplus remaining after total cost are deducted from total revenue and the basis on which tax is. Profitability is the primary goal of all business ventures.

Sales Volume This is the quantity or number of product sold or services provided by a company in a particular period of time. Sales volume can be seen as the volume of goods sold in number or quantity of units during the normal operation.

Market Share Market share is the percentage of an industry or market's total sales that is earned by a particular company over a specified time period. Market share is calculated by taking the company's sales over a period and dividing it by total sales of the industry over the same period. It can also be described as a percentage of total sales volume in a market captured by a brand, product or company. Market share is said to be a key indicator of market competitiveness that is, how well a firm is doing against its competitors.

Losses in market share can signal serious long-term problems that require strategic adjustments.

\subsubsection{Business Environment, in Covid -19 pandemic}

Business Environment has been defined as the sum or collection of all internal and external factors such as employees, customers' needs and expectations, supply and demand, management, clients, suppliers, owners, activities by government, innovation in technology, social trends, market trends, economic changes including the recent Covid-19 and its various variants. Covid-19 has shape how business relate with their customers and with their competitors.

Coronaviruses are a big family of different viruses, some of which are the cause of common cold and others infect animals, including bats, camels, and cattle. SARS-CoV-2, the coronavirus that causes COVID-19 was first detected in Wuhan, China, in late 2019 and has since then set off a global pandemic. The virus (SARS-CoV-2) was said to originated in bats like coronaviruses behind Middle East respiratory syndrome (MERS) and severe acute respiratory syndrome (SARS) got started, SARS-CoV-2 jumped to humans at one of Wuhan's open-air "wet markets" (market where customers buy fresh meat and fish, including animals that are killed on the spot). Within a months, this particular variant spread to over 98 countries around the world, becoming the dominant variant in more than a dozen of those countries, including India, the U.K., Israel and the United States. The new variant of Covid-19 called delta variant is now responsible for more than $83 \%$ of COVID-19 cases being reported in the U.S. and, with only $48 \%$ of the total U.S. population fully vaccinated (World Health Organization (WHO), 2021).

Coronavirus Disease 2019 (COVID-19) was declared as pandemic by the World Health Organization on March 11th, 2020 mainly due to the speed and scale of the transmission of the disease (WHO, 2020). Hindson (2020) in agreement with findings of Wrapp, Wang, Corbett, Goldsmith, Hsieh, Abiona, Graham and McLellan, (2020) opined that SARS-CoV-2 can be transmitted human to human by respiratory droplets, close contact with diseased patients, and possibly by fecal-oral and aerosol contact.

It was recently shown that airborne transmission is highly virulent and represents the dominant route to spread the disease (Zhang, Li, Zhang, Wang, Molina; 2020). Mitigation measures adopted include social distancing and wearing of masks, to partial and total lockdown which affected businesses in large scale. Majority of SARS-CoV-2 infected individuals ( $80 \%$ ) are asymptomatic or present mild symptoms most likely due to a good immune response able to control the advance of the disease. There is evidence that these asymptomatic people can infect others with SARS-CoV-2. In the other hand, symptomatic individuals may evolve to more severe symptoms and eventual death. The best way to prevent transmission and illness is to avoid being exposed to the virus. Therefore, some recommendations include wash hands often, avoid close contact, cover mouth and nose with a mask, cover coughs and sneezes, and clean and disinfect frequently touched surfaces daily. In this regard, wearing of face masks in public corresponds to the most effective means to prevent inter-human transmission, it is as shown in figure 1 below;

The worldwide Coronavirus pandemic of 2020 has presented an unprecedented set of health and increasing economic challenges for countries around the world. As infection rates have soared to over46 million worldwide with deaths related to coronavirus reaching almost 2 million at the time of writing. 
Figure 1: Effective means to prevent inter-human transmission

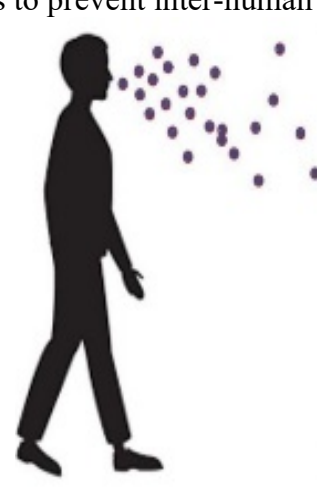

Source: WHO, (2020)

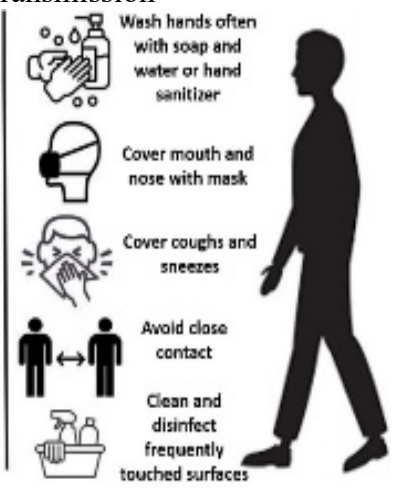

daily

2.2.5 Conceptual Framework

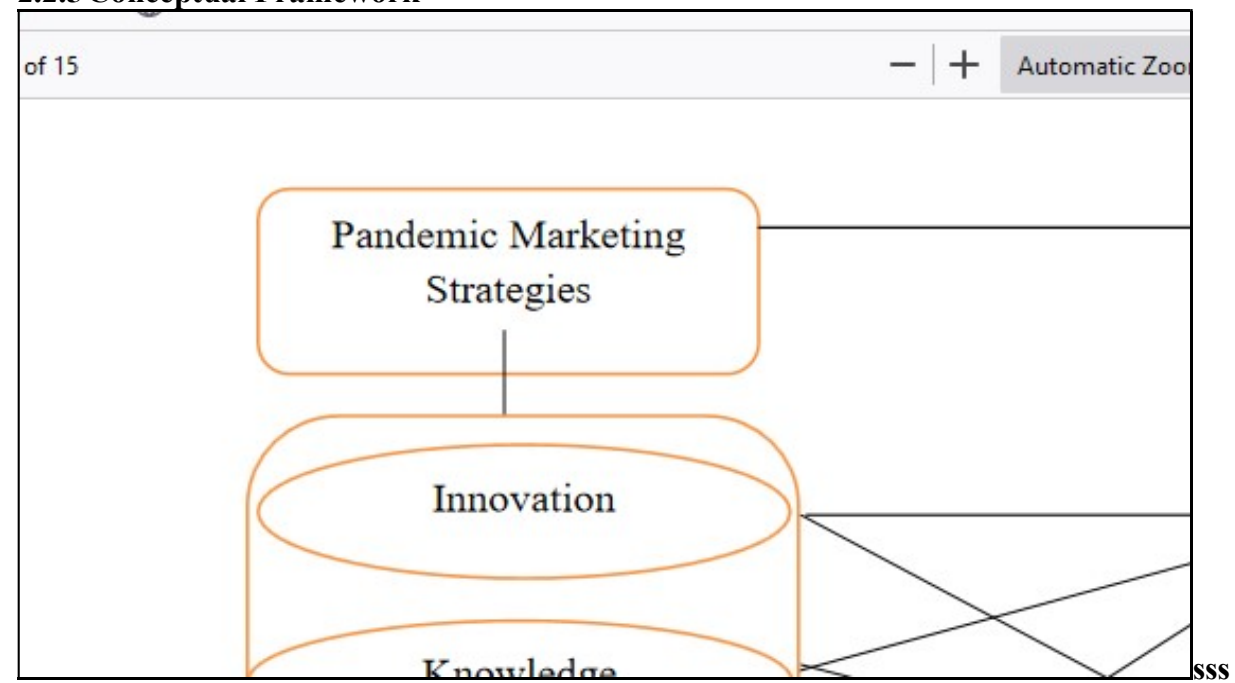

Sources: Adopted from Dash and Chakraborty (2021)

\subsection{Relationship between Marketplace and Customer Needs in Covid-19 Era}

Marketing is part of process of managing profitable relationships, by attracting new customers and keeping current customers by delivering satisfaction. Marketing must be understood in the sense of satisfying customer needs. Bonadio, Huo, Levchenko, and Pandalai-Nayar, (2020) defined marketing as the process by which companies create value for customers and build strong customer relationships to capture value from customers in return. They identified five core customer and marketplace concepts as;

* Customer needs, wants and demands. Human needs are states of felt deprivation and can include physical, social and individual needs. Wants are the form human needs take as they are shaped by culture and individual personality. Demands are human wants that are backed by buying power.

* Market offerings are a combinations of products, services and experiences offered to a market to satisfy a need or want. These can be physical products, but also services - activities that are essentially intangible. The phenomenon of marketing myopia is paying more attention to company products, than to the underlying needs of consumers.

* Value and satisfaction are key building blocks for customer relationships.

* Exchanges are the acts of obtaining a desired object form someone by offering something in return. Marketing consists of actions trying to build an exchange relationship with an audience.

* A market is the set of all actual and potential buyers of a product or service. Marketing involves serving a market of final consumers in the face of competitors.

\subsubsection{Designing a customer-driven marketing strategy}

Marketing management is the art and science of choosing target markets and building profitable relationships with them (Kotler; 2007). The aim is to find, attract, keep and grow the targeted customers by creating and delivering superior customer value. The target audience can be selected by dividing the market into customer segments (market segmentation) and selecting which segments to go after (target marketing). A company must 
also decide how to serve the targeted audience, by offering a value proposition. A value proposition is the set of benefits or values a company promises to deliver.

$\mathrm{Li}$, and Calantone, (1998) posited that there are five alternative concepts that companies use to carry out their marketing strategy.

1. The production concept: the idea that consumers will favour products that are available and highly affordable and that the organisation should therefore focus on improving production and distribution efficiency.

2. The product concept: the idea that consumers will favour products that offer the most quality, performance, and features and that the organisation should therefore devote its energy to making continuous product improvements.

3. The selling concept: the idea that consumers will not buy enough of the firm's product, unless it undertakes a large-scale selling and promotion effort.

4. The marketing concept: the idea that achieving organisational goals depends on knowing the needs and wants of target markets and delivering the desired satisfactions better than competitors do. It can be regarded as an "outside-in view".

5. The societal marketing concept is the idea that a company's marketing decisions should consider consumer wants, the company's requirements, consumers' long-term interests and society's long-term interests. Companies should deliver value in a way that maintains consumers and society's well-being.

2.3.2 Constructing an integrated marketing plan

A marketing strategy outlines which customers it will serve and how it will create value. The marketer develops an integrated marketing plan that will deliver value to customers. It contains the marketing mix: the tools used to implement the strategy, which are the four Ps: product, price, place and promotion.

Building customer relationships: The first three steps all lead to this one: building profitable customer relationships. Customer relationship management (CRM) is the overall process of building and maintaining profitable customer relationships by delivering superior customer value and satisfaction. The crucial part here is to create superior customer-perceived-value, which is the customer's evaluation of the difference between all the benefits and all the costs of a marketing offer, in relation to those of competing offers and superior customer satisfaction, which is the extent to which a product's perceived performance matches a buyer's expectations. Customer delight can be achieved by delivering more than promised.

Customer relationships exist at multiple levels. They can be basic relationships or full partnerships and everything in between. In current times, companies are choosing their customers more selectively. New technologies have paved the way for two-way customer relationships, where consumers have more power and control. The marketing world is also embracing customer-managed relationships: marketing relationships in which customers, empowered by today's new digital technologies, interact with companies and with each other to shape their relationships with brands. A growing part of this dialogue is consumer-generated marketing: brand exchanges created by consumers themselves, by which consumers are playing an increasing role in shaping their own brand experiences and those of other consumers.

Today's marketers often work with a variety of partners to build consumer relationships. Partner relationship management means working closely with partners in other company departments and outside the company to jointly bring greater value to customers. These partners can be inside the company, but also outside the firm. The supply chain is a channel, from raw material to final product, and the companies involved can be partners through supply chain management.

Capturing customer value: The final step of the model involves capturing value. Customer lifetime value is the value of the entire stream of purchases that the customer would make over a lifetime of patronage. Companies must aim high in building customer relations, to make sure that customers are coming back. Good CRM can help increase the share of customer, the portion of the customer's purchasing that a company gets in its product categories. Customer equity is the total combined customer lifetime values of all of the company's customers. It is the future value of the company's customer base. When building relationships, it is important to build the right relationships with the right customers. Customers can be high- or low-profitable and short-term or long-term oriented.

The world is characterized by dynamism which is compounded the recent pandemic named Covid -19 which totally revolutionized sales management and the market place. Total lockdown as a result of pandemic has brought untold hardship, economic crisis resulted leading to uncertainty economic environment, where consumers are more careful when spending their money. The technology boom of the digital age leads to an increase in connectedness and information. It provides marketers with new ways to track customers and create products based on their needs. It brought a new way of communicating and advertising. The most dramatic change in technology is the Internet, a vast public web of computer networks that connects users of all types all around the world to each other and an amazingly large information repository. 


\subsection{Theoretical Review- Resource Based View (RBV)}

Resource Based View (RBV) analyzes and interprets resources of the organizations to understand how organizations achieve sustainable competitive advantage. The RBV focuses on the concept of difficult-to-imitate attributes of the firm as sources of superior performance and competitive advantage (Barney, 2018). The RBV takes an 'inside-out' view or firm-specific perspective on why organizations succeed or fail in the market place (Dicksen, 1996). According to this theory an organization can be considered as a collection of physical resources, human resources and organizational resources (Amit and Shoemaker, 2003). Resources of organizations that are valuable, rare, imperfectly imitable and imperfectly substitutable are main source of sustainable competitive advantage for sustained superior performance (Barney, 1991).

RBV was traced to Barney (1994), however, some scholars argue that there was evidence for a fragmentary resource-based theory from the 1930s. RBV proposes that firms are heterogeneous because they possess heterogeneous resources, meaning firms can have different strategies because they have different resource mixes. Hence RBV theory opined that any valuable resource must fulfill 'VRIN' criteria in order to provide competitive advantage and sustainable performance. A 'VRIN' criterion is explained as follow;

Valuable (V): Resources are valuable if it provides strategic value to the firm. Resources provide value if it helps firms in exploiting market opportunities or helps in reducing market threats. There is no advantage of possessing a resource if it does not add or enhance value of the firm;

Rare (R): Resources must be scarce and difficult to find among the existing and potential competitors of the firm. The resources must be unique to offer competitive advantages. Resources that are possessed by a several firms in the market place cannot provide competitive advantage, as they cannot design and execute a unique business strategy in comparison with other competitors;

Imperfect Imitability (I): Imperfect imitability means making copy or imitate the resources will not be feasible. There are so many inhibition for product imitability which are; difficulties in acquiring product, ambiguous relationship between capability and competitive advantage or complexity of resources. Resources can be basis of sustained competitive advantage only if firms that do not hold these resources cannot acquire them;

Non-Substitutability (N): Non-substitutability of products implies that resources cannot be substituted by another alternative product. Therefore competitor can't achieve same performance by replacing resources with other alternative resources.

RVB therefore posited that valuable product must enable a firm to do things and behave in ways that lead to high sales, low costs, high margins, or in others ways add financial value to the firm. Barney emphasized that resources are valuable when they enable a firm to conceive of or implement strategies that improve its efficiency and effectiveness. Therefore RBV helps managers of any firms to understand that competences can be perceived as a firms' most important asset and, at the same time, to appreciate how those assets can be used to improve business performance. Campbell and Luchs, (2017) are of opinion that RBV of the firm accepts that attributes related to past experiences, organizational culture and competences are critical for the success of the firm.

\subsection{Empirical Review}

It is of prime advantage for the firm to possess the ability of consistent and planned activities to meet and exceed customer preferences and value that can be regarded as customer performance. This customer performance is achieved by the firm regardless of the approach of marketing pursued meaning either undertaking standardization or adaptation. In order for a company to securely adapt to varying international markets, the marketing strategy should take into consideration the internal and external business environment that affects a company positively to revel in greater performance. The influence of marketing strategy- product focus on various dimensions including actual and augmented product factors on performance in international markets, has quite received attention by numerous researchers. The study conducted by Aremu and Lawal (2012) which employed composite export performance measures, focused on product design marketing mix element found conducive to performance of companies pursuing global marketing in that it can serve product adaptation as a means of differentiation for rival's products and influence overseas customer attitudes (customer performance) toward a firm's product. In overall, the study by Aremu and Lawal (2012) found product design and style to have a significant positive effect on firm performance.

While other studies researched on the relationship between product quality and firm performance in international markets in which the relationship is found to be positively associated. The provision of high-quality product to customers has been postulated to augment the value associated with customer performance. Prior studies reveal two observations regarding quality of product in line with the marketing strategy that are important. However, the export product marketing mix for companies is usually of a narrower range than that offered domestically, because of financial constraints and operational difficulties associated with global marketing activities (Aremu and Lawal, 2012).

First, it significantly reflects a customer-oriented posture because the firm engaging in global marketing systematically evaluates consumer and buyer behavior and host market characteristics that improve the firm's 
total performance (Douglas and Wind, 1987). Second, product adaptation strategy can lead to greater financial performance such as profitability, as a quality product-market match can result in greater customer satisfaction thus improving customer performance that is one of the outcome in our research model, which consequently allows for greater pricing freedom for the firm.

Third, pressures associated with meeting a great degree of specific market requirements on international level often demand creative and innovative marketing strategy, which may bring about additional products for a firm's domestic and international markets. Thus far, product adaptation is a suitable strategy toward market responsiveness as it offers the development of new products that meet the needs of a changing marketplace.

Many researchers have emphasized the importance of promotional mix to business markets as a valuable tool for achieving performance. Sales, financial and customer performance is achieved through promotional mix by gaining experience in the opportunities and problems arising in specific export markets, boosting communication, personalizing relationships, and cultivating a team spirit with customers abroad, and providing timely response and immediate support to the export venture's needs.

The study by Ambler and Puntoni, (2004) examined six promotion-related variables, an so on, advertising, sales promotion, personal selling, trade fairs, personal visits, and promotion adaptation, for their effects on export performance. Most of the promotional related variables were found to be positively linked to firm performance. Notably, advertising was the most widely researched variable of promotional mix, based on the notion that with sound advertising procedures the firm can communicate information, constantly remind, and persuade foreign customers to buy the products and, therefore, generate more sales.

\section{Section III: Research Methodology}

This chapter is give detail of the method adopt for the analyses of the project, it contain research design, sampling and sampling techniques, sources and method of data collection, and method of data analyses.

\subsection{Research Design}

A research design can be explained as the detailed blueprint used to guide a research study toward its objectives (Asika, (1991). A design is used to structure the research, to show how all of the major parts of the research project. This research project adopted survey research design where data will be gather from selected sample size (respondents) using questionnaire as instrument of data collection.

\subsection{Population and Sample Size of the Study}

The target population of the study consists of manufactures of Fast Moving Consumer Good (FMCG) in Lagos Nigeria. Staff of \& Up Bottling Company is chosen as the case study Convenience sampling technique is used to draw the sample size.

\subsection{Sources of Data Collection}

This study utilized primary source of data. Primary data mainly come from field work activities in the form of responses to questionnaire from selected samples.

\subsection{Research Instrument}

The research instrument is a questionnaire designed by the researcher to obtain responses from respondents. To encourage high response rate of respondents, anonymity of respondents was ensured and communicated to all respondents before they answered the questions. The questionnaire is a carefully structured statement or questions prepared by a researcher and administered to the respondents to obtain in writing some information. The study utilized structured questionnaires that is drawn from the critical variables of the study. The questionnaire is divided into two sections. Namely, section A and section B. Section A comprised of items relating to respondent's demographic data while B comprised of statements that explained essential variables of the study. Each statement had a closed-ended structure and rated on a five-point Likert scale method of Strongly agree $=5$, Agree $=4$, Indifferent $=3$, Disagree $=2$ and Strongly disagree $=1$ upon which each respondent is expected to rate his/her self-opinion to these questions. The Likert scales and their ratings provided on the questionnaire serve as indicators for appropriate responses

Apparently, these questions are assumed to have much significance on the subject matters, and the questions are precise and direct to avoid ambiguous response so they were carefully chosen for this research.

\subsection{Validity and Reliability Test}

Validity refers to the degree to which an instrument accurately measures what it intends to measure. Face and content validity test were employed in this project and to complement the instrument, was designed making use of all the variables in the subject matter of the work. The draft of the questionnaire was given to experts in the field of marketing. 
In order to ensure validity of the work test- retest method was used on twenty (20) of the final respondents. The reliability of a measure can be seen from the view point of the extent to which measure is error- free (Stone, 2005). The test of reliability adopt test-retest method using Cronbach's alpha. The higher the $\alpha$ coefficient, the more the items have shared covariance and probably measure the same underlying concept. The coefficient of Cronbach alpha for this is 73.0. This show that the test items for the project is reliable and capable of replicate.

\subsection{Administration of Data}

One hundred (150) copies of the questionnaire were distributed in all the department of Seven Up Nigeria Plc used as the case study. The analyses of the returned questionnaires were thus;

Table 1: Distribution and Returned of Questionnaires

\begin{tabular}{|l|l|l|l|}
\hline SN & Department & No Distributed & No Returned \\
\hline 1 & 7- UP Plc & 20 & 12 \\
\hline 2 & Rites Food Industries Ltd & 20 & 20 \\
\hline 3 & Nigerian Bottling Company Plc & 20 & 15 \\
\hline 4 & Chi Nigeria Ltd & 20 & 12 \\
\hline 5 & Lacasera Nigeria Ltd & 20 & 11 \\
\hline 6 & Flour Mills of Nigeria Plc & 20 & 10 \\
\hline 7 & Cadbury Nigeria Plc & 30 & 25 \\
\hline & Total & 150 & 105 \\
\hline
\end{tabular}

Source: Field study (2021)

One hundred and fifty (150) copies of questionnaire, one hundred and five question were returned time for the analyses. Out of these three were not filled and two was wrongly filled.

\subsubsection{Analysis of Bio Data}

In the responses to question 1, name were given and since it is optional majority refuse to put their name or pseudo names. Hence the purpose is to attach identity to each questionnaire.

Question 2: Gender: Analyses of Question 1 shows respondents' distribution according to sex. The majority of the respondents are male with sixty five (65) respondents or 65 percent of the total respondents and female forms the rest of the group. The Pie Chart below depicts the sex distribution.

\section{Figure 2: $\quad$ Gender distribution of Respondents}

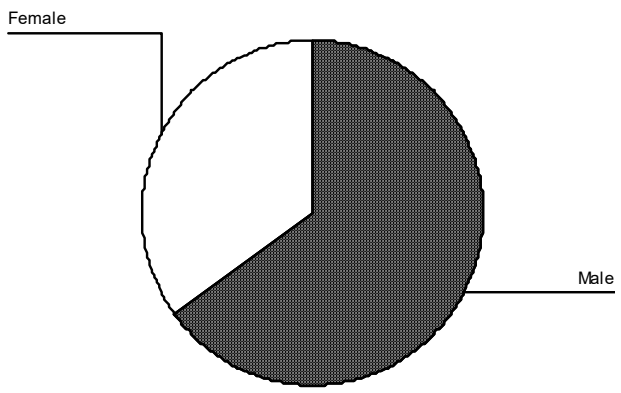

Source: Researcher's Field Study

The analyses that the respondents' age distribution varies with the group of 31-40 years with 33 respondents of 33 percent of the total respondents, while the least group are age group of $21-30$ years with 8 respondents or 8 percent. Also the Marital Status show that Married group are majority with 41 percent of the total respondents or 41 respondents. The group of singles comprises 40 respondents or 40 percent of the total respondents, 9 respondents or 9 percent are widows or widowers. While the distribution of respondents according to Religion Status showed that, 63 respondents or 63 percent of the respondents are Christian which is the majority 17 respondents are Muslim which form 17 percent and the rest belong to other religion organization. While analyses of distribution of respondents according to educational qualification show that 52 respondents or 52 percent of the respondents have General Certificate of Education and Senior Secondary Certificate Education the group with Ordinary National Diploma are 17 respondents or 17 percent. Also the respondents that have Bachelor of Science and Higher National Diploma in various disciplines are 20 respondents or 20 percent of the total respondents. Respondents that have other higher certificates are 11 forming 11 percent of the total respondents. Also the analyses of distribution according to Organisations where they work.. Also analyses of respondents' social status show that distribution of respondents according to Social Status, the respondents who are supervisor are 44 respondents or 44 percent, that of middle management are 34 respondents or 34 percent while none of the respondents belong to other categories. Also the length of years spent in the Organization show that respondents who have served the organization from 11 years and above are majority with 44 respondents or 44 percent while 
those that served below 5 years are 22 respondents or 22 percent.

\subsubsection{Analysis of Section B}

Majority of the respondents with 65 percent strongly agree that shut down as a result of Covid-19 pandemic has affect organizations' sales turn over while 1percent of the total respondents disagree. Majority of the respondent with 49 percent strongly agree that internet marketing strategies helped my organization in achieve its marketing objective while 1 percent of the total respondents disagree. Also majority of the respondent with 46 percent strongly agree that internet marketing strategies adopted during Covid-19 Era has enhances sales during lock down while 2 percent of the total respondents disagree. Majority of the respondent with 50 percent agree that other creative marketing strategies adopted during Covid-19 Era has enhances organizations' sales while 1 percent of the total respondents strongly disagree. Majority of the respondent with 52 percent strongly agree that internet marketing strategies adopted during Covid-19 Era while 1 percent of the total respondents strongly disagree. Majority of the respondent with 50 percent agree that internet marketing strategy enhances sales during lock down while 1 percent of the total respondents strongly disagree. In the analyses, majority of the respondent with 49 percent agree that Internet marketing strategies adopted in the organization help in increasing the sales volume during Coviid-19 pandemic while 1 percent of the total respondents strongly disagree. In the analyses also 44 percent who are the majority agree that Internet marketing strategy adopted during Coviid-19 pandemic has increase productivity in my organization while 2 percent of the total respondents strongly disagree.

Majority of the respondent with 49 percent agree that Internet marketing strategy adopted during Coviid-19 pandemic has enhance sales promotion while 1 percent of the total respondents strongly disagree. The analyses shows majority of the respondent with 49 percent agree that Internet marketing strategy adopted during Coviid19 pandemic has help in achieving marketing objective in my organization while 2 percent of the total respondents strongly disagree. 59 percent strongly agree that Internet marketing strategies adopted during Covid19 Era has been effective while 1 percent of the total respondents strongly disagree.

Majority of the respondent with 45 percent agree that Internet marketing strategies adopted during Covid-19 Era has positive related to the sales growth of the organization while 1 percent of the total respondents strongly disagree. Majority of the respondent with 49.7 percent strongly agree that Internet marketing strategies adopted during Covid-19 Era help to create customer.

\subsubsection{Testing of Hypothesis I}

Question 1 to 5 is used to test hypothesis I

Ho: There is no significant relationship between the pandemic (Covid-19) and strategic and other creative marketing strategies adopted.

Table 2: Chi Square $\left(\mathrm{X}^{2}\right)$ Extract

\begin{tabular}{|c|c|c|c|c|c|c|c|c|}
\hline & Response & Freq & $\%$ & $\mathrm{X}^{2} \mathrm{Cal}$ & $\mathrm{X}^{2}$ Table & DF & $\mathbf{L S}$ & Remarks \\
\hline \multirow[t]{6}{*}{10} & $\mathrm{SA}=$ Strongly Agree & 65 & 65.0 & & & & & \\
\hline & $\mathrm{A}=$ Agree & 30 & 30.0 & & & & & \\
\hline & $\mathrm{U}=$ Undecided & 3 & 3.0 & & & & & \\
\hline & $\mathrm{D}=$ Disagree & 1 & 1.0 & & & & & \\
\hline & $\mathrm{SD}=$ Strongly Disagree & 1 & 1.0 & & & & & \\
\hline & Total & 100 & 100.0 & 558.417 & & 4 & & \\
\hline \multirow[t]{6}{*}{11} & $\mathrm{SA}=$ Strongly Agree & 49 & 49.0 & & & & & \\
\hline & $\mathrm{A}=$ Agree & 44 & 44.0 & & & & & \\
\hline & $\mathrm{U}=$ Undecided & 5 & 5.0 & & & & & \\
\hline & $\mathrm{D}=$ Disagree & 1 & 1.0 & & & & & \\
\hline & $\mathrm{SD}=$ Strongly Disagree & 1 & 1.0 & & & & & \\
\hline & Total & 100 & 100.0 & 431.028 & & 4 & & \\
\hline \multirow[t]{6}{*}{12} & $\mathrm{SA}=$ Strongly Agree & 46 & 46.0 & & & & & \\
\hline & $\mathrm{A}=$ Agree & 44 & 44.0 & & & & & \\
\hline & $\mathrm{U}=$ Undecided & 8 & 8.0 & & & & & \\
\hline & $\mathrm{D}=$ Disagree & 2 & 2.0 & & & & & \\
\hline & $\mathrm{SD}=$ Strongly Disagree & 0 & 0.0 & & & & & \\
\hline & Total & 100 & 100.0 & 377.083 & & 4 & & \\
\hline \multirow[t]{6}{*}{13} & $\mathrm{SA}=$ Strongly Agree & 40 & 40.0 & & & & & \\
\hline & $\mathrm{A}=$ Agree & 50 & 50.0 & & & & & \\
\hline & $\mathrm{U}=$ Undecided & 6 & 6.0 & & & & & \\
\hline & $\mathrm{D}=$ Disagree & 3 & 3.0 & & & & & \\
\hline & $\mathrm{SD}=$ Strongly Disagree & 1 & 1.0 & & & & & \\
\hline & Total & 100 & 100.0 & 385.722 & & 4 & & \\
\hline
\end{tabular}




\begin{tabular}{|l|l|l|l|l|l|l|l|l|}
\hline & Response & Freq & $\mathbf{0}$ & $\mathbf{X}^{2}$ Cal & $\mathbf{X}^{2}$ Table & DF & LS & Remarks \\
\hline \multirow{5}{*}{14} & SA= Strongly Agree & 52 & 52.0 & & & & & \\
\cline { 2 - 9 } & A = Agree & 40 & 40.0 & & & & & \\
\cline { 2 - 9 } & U= Undecided & 6 & 6.0 & & & & & \\
\cline { 2 - 9 } & D= Disagree & 1 & 1.0 & & & & \\
\cline { 2 - 9 } & SD= Strongly Disagree & 1 & 1.0 & & & & \\
\cline { 2 - 9 } & Total & $\mathbf{1 0 0}$ & $\mathbf{1 0 0 . 0}$ & 416.389 & & 4 & & \\
\hline Total & & & 2168.639 & 39.997 & 20 & 0.05 & Sig. \\
\hline
\end{tabular}

$\mathrm{X}^{2} \mathrm{Cal}=2168.639, \mathrm{X}^{2}$ table $=39.997$, Degree of Freedom $(\mathrm{df})=20$ at 0.05 Level of Significant (LS)

Decision:

Table 1 above presents the Chi-square, the result indicates that the Chi square calculated $\left(\mathrm{X}_{\text {cal }}^{2}\right)$ at 2168.639 while Chi square table $\left(\mathrm{X}^{2} \mathrm{Tab}\right)$ at 39.997 with degree of Freedom $(\mathrm{df})=20$ at 0.05 Level of Significant (LS). It is observed that Chi square Table $\left(\mathrm{X}^{2} \mathrm{Tab}\right)$ is less than Chi square $\left(\mathrm{X}^{2}\right)$ Calculated $\left(\mathrm{X}^{2} \mathrm{Cal}\right)$. Therefore, reject the null hypothesis that there is no significant relationship between the pandemic (Covid-19) and strategic and other creative marketing strategies adopted.

\subsubsection{Testing of Hypothesis II}

Question 6 to 10 is used to test hypothesis I

Ho: Strategic and other creative marketing strategies adopted during Covid-19 Era does not have significant effect on organization profitability.

Table 3: Chi Square $\left(\mathrm{X}^{2}\right)$ Extract

\begin{tabular}{|c|c|c|c|c|c|c|c|c|}
\hline & Response & Freq & $\%$ & $\mathrm{X}^{2} \mathrm{Cal}$ & $\mathrm{X}^{2}$ Table & DF & $\mathbf{L S}$ & Remarks \\
\hline \multirow[t]{6}{*}{15} & $\mathrm{SA}=$ Strongly Agree & 41 & 41.0 & & & & & \\
\hline & $\mathrm{A}=$ Agree & 50 & 50.0 & & & & & \\
\hline & $\mathrm{U}=$ Undecided & 5 & 5.0 & & & & & \\
\hline & $\mathrm{D}=$ Disagree & 3 & 3.0 & & & & & \\
\hline & $\mathrm{SD}=$ Strongly Disagree & 1 & 1.0 & & & & & \\
\hline & Total & 100 & 100.0 & 402.083 & & 4 & & \\
\hline \multirow[t]{6}{*}{16} & $\mathrm{SA}=$ Strongly Agree & 42 & 42.0 & & & & & \\
\hline & $\mathrm{A}=$ Agree & 49 & 49.0 & & & & & \\
\hline & $\mathrm{U}=$ Undecided & 5 & 5.0 & & & & & \\
\hline & $\mathrm{D}=$ Disagree & 3 & 3.0 & & & & & \\
\hline & $\mathrm{SD}=$ Strongly Disagree & 1 & 1.0 & & & & & \\
\hline & Total & 100 & 100.0 & 398.972 & & 4 & & \\
\hline \multirow[t]{6}{*}{17} & $\mathrm{SA}=$ Strongly Agree & 41 & 41.0 & & & & & \\
\hline & $\mathrm{A}=$ Agree & 44 & 44.0 & & & & & \\
\hline & $\mathrm{U}=$ Undecided & 11 & 11.0 & & & & & \\
\hline & $\mathrm{D}=$ Disagree & 2 & 2.0 & & & & & \\
\hline & $\mathrm{SD}=$ Strongly Disagree & 2 & 2.0 & & & & & \\
\hline & Total & 100 & 100.0 & 322.083 & & 4 & & \\
\hline \multirow[t]{6}{*}{18} & $\mathrm{SA}=$ Strongly Agree & 39 & 39.0 & & & & & \\
\hline & $\mathrm{A}=$ Agree & 49 & 49.0 & & & & & \\
\hline & $\mathrm{U}=$ Undecided & 9 & 9.0 & & & & & \\
\hline & $\mathrm{D}=$ Disagree & 2 & 2.0 & & & & & \\
\hline & $\mathrm{SD}=$ Strongly Disagree & 1 & 1.0 & & & & & \\
\hline & Total & 100 & 100.0 & 375.583 & & 4 & & \\
\hline \multirow[t]{6}{*}{19} & $\mathrm{SA}=$ Strongly Agree & 31 & 31.0 & & & & & \\
\hline & $\mathrm{A}=$ Agree & 49 & 49.0 & & & & & \\
\hline & $\mathrm{U}=$ Undecided & 14 & 14.0 & & & & & \\
\hline & $\mathrm{D}=$ Disagree & 4 & 4.0 & & & & & \\
\hline & $\mathrm{SD}=$ Strongly Disagree & 2 & 2.0 & & & & & \\
\hline & Total & 100 & $\mathbf{1 0 0 . 0}$ & 285.694 & & 4 & & \\
\hline \multicolumn{2}{|c|}{ Total } & & & 1784.415 & 39.997 & 20 & 0.05 & Sig. \\
\hline
\end{tabular}

$\mathrm{X}^{2} \mathrm{Cal}=1784.415, \mathrm{X}^{2}$ table $=39.997$, Degree of Freedom $(\mathrm{df})=20$ at 0.05 Level of Significant $(\mathrm{LS})$

Decision:

From the above computation, Chi Square Table $\left(\mathrm{X}^{2} \mathrm{Tab}\right)$ at 39.997 is less than Chi Square Calculated $\left(\mathrm{X}^{2}\right.$ cal $)$ at 1784.415 therefore reject null hypothesis and accept alternate hypothesis that strategic and other creative 
marketing strategies adopted during Covid-19 Era does not have significant effect on organization profitability.

\subsubsection{Testing of Hypothesis III}

Question 11 to 15 is used to test hypothesis I

\section{Hypothesis III}

Ho: Strategic and other creative marketing strategies adopted during Covid-19 Era does not have significant effect on organization productivity.

Table 4: Chi Square $\left(\mathrm{X}^{2}\right)$ Extract

\begin{tabular}{|c|c|c|c|c|c|c|c|c|}
\hline & Response & Freq & $\%$ & $\mathrm{X}^{2} \mathrm{Cal}$ & $\mathrm{X}^{2}$ Table & DF & LS & Remarks \\
\hline \multirow[t]{6}{*}{20} & $\mathrm{SA}=$ Strongly Agree & 59 & 59.0 & & & & & \\
\hline & $\mathrm{A}=$ Agree & 36 & 36.0 & & & & & \\
\hline & $\mathrm{U}=$ Undecided & 3 & 3.0 & & & & & \\
\hline & $\mathrm{D}=$ Disagree & 1 & 1.0 & & & & & \\
\hline & $\mathrm{SD}=$ Strongly Disagree & 1 & 1.0 & & & & & \\
\hline & Total & 100 & 100.0 & 497.583 & & 4 & & \\
\hline \multirow[t]{6}{*}{21} & $\mathrm{SA}=$ Strongly Agree & 45 & 45.0 & & & & & \\
\hline & $A=$ Agree & 45 & 45.0 & & & & & \\
\hline & $\mathrm{U}=$ Undecided & 6 & 6.0 & & & & & \\
\hline & $\mathrm{D}=$ Disagree & 3 & 3.0 & & & & & \\
\hline & $\mathrm{SD}=$ Strongly Disagree & 1 & 1.0 & & & & & \\
\hline & Total & 100 & 100.0 & 377.361 & & 4 & & \\
\hline \multirow[t]{6}{*}{22} & $\mathrm{SA}=$ Strongly Agree & 50 & 50.0 & & & & & \\
\hline & $\mathrm{A}=$ Agree & 40 & 40.0 & & & & & \\
\hline & $\mathrm{U}=$ Undecided & 5 & 5.0 & & & & & \\
\hline & $\mathrm{D}=$ Disagree & 3 & 3.0 & & & & & \\
\hline & $\mathrm{SD}=$ Strongly Disagree & 2 & 2.0 & & & & & \\
\hline & Total & 100 & 100.0 & 387.583 & & 4 & & \\
\hline \multicolumn{2}{|c|}{ Total } & & & 2092.416 & 39.997 & 20 & 0.05 & Sig. \\
\hline
\end{tabular}

$\mathrm{X}^{2} \mathrm{Cal}=2092.416, \mathrm{X}^{2}$ table $=39.997$, Degree of Freedom $(\mathrm{df})=20$ at 0.05 Level of Significant (LS)

Decision:

Table 3 above presents the Chi-square; the result indicates that the Chi square calculated $\left(\mathrm{X}^{2}\right.$ cal $)$ at 2092.416 while Chi square table $\left(\mathrm{X}^{2} \mathrm{Tab}\right)$ at 39.997 with degree of Freedom $(\mathrm{df})=20$ at 0.05 Level of Significant (LS). It is observed that Chi square Table $\left(\mathrm{X}^{2} \mathrm{Tab}\right)$ is less than Chi square $\left(\mathrm{X}^{2}\right)$ Calculated $\left(\mathrm{X}^{2} \mathrm{Cal}\right)$. Therefore, reject the null hypothesis that strategic and other creative marketing strategies adopted during Covid-19 Era does not have significant effect on organization productivity.

\section{Section IV: Conclusion and Recommendation}

This section presents a summary of the major findings from the study based on the research objective, conclusions and recommendations are derived from the findings and conclusions of the study.

\subsection{Summary of Findings}

In the analyses, it was discovered that that the result indicates that there are relationship between the pandemic (Covid-19) and strategic and other creative marketing strategies adopted. The pandemic has forced business concern to adopt alternative method of doing business and especially marketing.

It was also discovered that strategic and other creative marketing strategies adopted during Covid-19 Era does have effect on organization profitability. Because of the responses of most government to the pandemic ranging from social distancing, to outright lockdown has really affect the social life as well as the demand for most FMCG like product of Seven up bottling company under study which warrant the company to seek alternative plan for marketing of their products. It was discovered that internet marketing and other creative marketing strategies adopted during Covid-19 Era has significant relationship to organization profitability. The strategy has been able to give provide the essential needs of the consumers even during lockdown and thereby give customer satisfaction

It was also established that strategic and other creative marketing strategies adopted during Covid-19 Era have effect on organization productivity. It certain that Covid-19 pandemic has constrained work environment with most businesses going virtual, and numerous organizations made the required changes, effectively. This paper discovered organization rise to the occasion by proffering solution to maintain productivity during the period. One major strategy adopted which is internet marketing and other creative marketing strategies adopted during Covid-19 Era have effect on organization productivity. In Seven-up Nigeria Bottling Company marketing strategy adopted has help in efficiency and effectiveness management of the resources and achieve customer 
satisfaction during the period of pandemic. The study also revealed that internet marketing and other creative marketing strategies adopted during Covid-19 Era have impact on customers' satisfaction. It was also discovered from literature that promotional strategy and product promotion using internet marketing during the lockdown has increase customers' loyalty during the pandemic period.

\subsection{Conclusion}

A number of theories and models have been used in this study to classify the traditional use of marketing strategies as it's enhance performance to organizations/institutions. By and large, the study reveals that the organization understudied seven in number use niche markets as one of its key strategic marketing performance drivers on sales, representatives and its entire market structures. However this pointed that effective and efficient use of marketing strategy enhances not only sales performance to organization but also develops, and enhances productivity to employees. It is on the premises of this conclusion that the study recommend as below.

\subsection{Recommendations}

In view of the findings of this study, the following recommendations are made;

* Seven-Up Bottling Company is moving the conglomerate into more growth stages, the marketing strategy needs to change. Although the strategic objective is still fast growth, focus should move on to developing new market segments, and also finding new uses for the product and building market share.

* The target market share must change from the innovators to the more typical segments that constitute the mass market.

* The business is now likely to have important competitors whose strategies need to be analyzed and understood if competitive advantage is to be maintained. The core strategy now becomes more complex; the organization are likely to have a variety of offers, each aimed at a target segment and each seeking to present an appropriate differential advantage.

* The marketing mix should also change during the growth stage. However, the business should seek to introduce innovative new products in the range that can obtain 'premium prices and encourage innovative new products in the range that can obtain premium prices and encourage customers to trade up.

* Also high advertising and promotional expenditures will still be necessary to support market share aspirations.

* Finally, Seven-up Nigeria Plc should be seeking to broaden distribution channels to increase availability and service to its target customers.

\section{REFERENCES}

Achumba, I. (2000). Strategic Marketing Management in the $21^{\text {st }}$ Century. U.S.A. Mac Williams and Capital Publishers Inc.

Amit, R. and Schoemaker, P. J. (1993). Strategic assets and Organizational rent; Strategic Management Journal, Vol. 13 (3).

Anderson, P. F. (1982). Marketing, strategic planning and the theory of the firm. Journal of Marketing; Vol. 46 (Spring).

Ansoff, H. I. (1957). Strategies for Diversification. Harvard Business Review, Vol. Vol. 25 (5).

Ansoff, H. I. (2008). Corporate Strategy. New York: McGraw-Hall.

Ansoff, H. I. (1969). Business Strategy. Baltimore. Madrid Penguin.

Aremu (2009). Asset stock accumulation and sustainability of competitive advantage. Journal o Management Science; Vol. 35 (1).

Asika, N. (2000): Research Methodology in the Behavioural Science. Lagos Longman Publishers

Boohnger, G. (2003) The capabilities of market-driven V organizations; Journal of Marketing, Vol. 58 (3).

Achumba, I. (2002). Strategic Marketing in the 21st Century; U.S.A: Williams and Capital Publishers Inc.

Coates, T. T. and McDermott, C. M. (2002). An exploratory analysis of new competencies: A resource based view perspective. Journal of Operations Management, Vol. 20 (4).

Day, G. (2014). The capabilities of market-driven organizations; Journal of Marketing: Vol. 58 (3).

Derricks, I. and Cool, K. (2001). Asset stock accumulation and sustainability of competitive advantage. Journal of Management Science; Vol. 35 (1).

Dickinson, R., Herbat, A. and O'Shaughnessy, J. (2019). Marketing concept and consumer orientation. European Journal of Marketing; Vol. 20(10).

Eisenhardt, K. M. and Martin, J. A. (2000). Dynamic capabilities: What are they? Strategic Management Journal, Vol. 21(10-11).

Fahy, J. (2000). The resource-based view of the firm: Some stumbling-blocks on the road to understanding sustainable competitive advantage. Journal of European Industrial Training, Vol. 24 (9). 
Kaplan, A.M. and Haenlein, M. (2010). Users of the world, unite! The challenges and opportunities of Social Media. Business Horizon Vol. 53 (5).

Matosas-López, L. The Management of Digital Marketing Strategies in Social Network Services: A Comparison between American and European Organizations. Journal of Open Innovation Technology Vol. 7 (5)

Usman, U.M.Z.; Jalal, A.N. and Musa, M.A. (2021). The impact of electronic customer relationship management on consumer's behavior. International Journal Advance Engineering Technology; Vol. 3 (5).

Singh, R.P. and Jain, D.V. (2017). A Study of the Impact of Electronic Customer Relationship Management on Customer Loyalty by Using Structural Equation Modeling in Banking Sector. Resources World; Vol. 8 (2). 